\title{
"OSTEOPETROSIS" IN THE FAIRBANK COLLECTION
}

\author{
F. T. HORAN, P. H. BEIGHTON
}

\begin{abstract}
The "osteopetrosis" section of the Fairbank Collection in the Radiology Museum of the Royal National Orthopaedic Hospital contains radiographs and case notes of twenty-two patients. This material has been reviewed in terms of modern concepts in an attempt to obtain a long-term follow-up and a firm diagnosis in each individual.

Nine patients proved to have the classical autosomal dominant form of osteopetrosis, four had the malignant autosomal recessive type, craniometaphyseal dysplasia was present in two kindreds and isolated individuals had pyknodysostosis, atypical craniodiaphyseal dysplasia and craniosclerosis with osteopathia striata. As these conditions differ greatly in their clinical and genetic prognoses, diagnostic categorisation is of practical importance.
\end{abstract}

Sir Thomas Fairbank (1876-1961) was particularly interested in rare bone diseases. Throughout his career he collected notes and radiographs of patients with such disorders and he became the authority on their diagnosis. In 1951 Sir Thomas published his classical monograph, An Atlas of Generalised Affections of the Skeleton, which was based on his collection. After his retirement he donated this material to the Radiology Museum of the Royal National Orthopaedic Hospital, London.

Records of patients with conditions characterised by varying degrees of increased bone density and abnormal skeletal modelling were grouped in the Collection under the heading of "osteopetrosis". With the accumulation of further knowledge a number of separate syndromes have been delineated from this general category. As they are distinctive in their clinical manifestations and modes of genetic transmission, an accurate diagnosis can usually be established. We have therefore reviewed the material within this section of the Collection and attempted a long-term follow-up and revision of the original diagnosis in each patient. Our findings are presented and discussed in this paper.

\section{METHOD OF INVESTIGATION}

The material pertaining to the twenty-two patients in the "osteopetrosis" group was reviewed. Information was initially sought from the original referring specialist or family doctor and efforts were made to re-establish contact with each patient. If other sources failed, the medical records unit of the Department of Health and Social Security at Newcastle was approached. Five patients had died and several others were lost to follow-up. However, much new clinical and genetic information was obtained and we were able to up-date the majority of case histories. Four patients were seen at the Royal National Orthopaedic Hospital or in their homes. The clinical, radiographic and genetic material thus obtained was analysed and an attempt was made to reach a precise diagnosis in each case.

\section{RESULTS}

One of the twenty-two sets of notes on the "osteopetrosis" cases was missing and in two instances details of more than one patient were documented. The major findings and the authors' diagnosis for each patient are shown in Table I.

Nine patients had classical benign autosomal dominant osteopetrosis, initially described by AlbersSchönberg (1904). Four had the malignant autosomal recessive form. Craniometaphyseal dysplasia was present in members of two kindreds. Pyknodysostosis, atypical craniodiaphyseal dysplasia and craniosclerosis with osteopathia striata were each diagnosed in single cases. One woman had luetic bone disease, a boy had a unique disorder in which bone sclerosis was associated with multiple abnormalities of the epiphyses of the digits and a young man had an undiagnosable syndrome of deafness, bone fragility and renal disease.

\section{FEATURES OF THE SYNDROMES}

Osteopetrosis. The autosomal dominant, benign or tarda form is characterised by a generalised increase in bony density with little disturbance of skeletal modelling (Johnston et al. 1968). Transverse fractures can occur through sclerotic areas. Dental caries may lead to osteomyelitis of the mandible or maxilla. Deafness and facial weakness due to cranial nerve entrapment are sometimes present. Rarely, medullary overgrowth causes marrow dysfunction and chronic anaemia. However, the condition usually produces no symptoms and it is often a chance radiographic finding.

F. T. Horan, M.Sc., F.R.C.S., Consultant Orthopaedic Surgeon, Cuckfield Hospital, Haywards Heath, Sussex RH17 5HQ, England. P. H. Beighton, M. D., Ph.D., F.R.C.P.(Ed)., Professor of Human Genetics, Medical School, University of Cape Town, Observatory, 7925, South Africa. 
F. T. HORAN, P. H. BEIGHTON

Table I. An analysis of the case material in the "osteopetrosis" section of the Fairbank Collection

\begin{tabular}{|c|c|c|c|c|c|c|}
\hline $\begin{array}{c}\text { Fairbank } \\
\text { Collection } \\
\text { number } \\
\text { (C2 section) }\end{array}$ & $\begin{array}{l}\text { Year seen } \\
\text { by } \\
\text { Sir Thomas }\end{array}$ & $\begin{array}{l}\text { Year of } \\
\text { birth }\end{array}$ & Sex & Major manifestations & Family history & Authors' final diagnosis \\
\hline 1 & 1923 & 1911 & $\mathbf{F}$ & Multiple fractures & & Osteopetrosis (AD) \\
\hline 2 & 1926 & 1919 & $\mathbf{F}$ & $\begin{array}{l}\text { Anaemia. Optic atrophy. } \\
\text { Fractures in childhood }\end{array}$ & & Osteopetrosis (AR) \\
\hline 3 & 1932 & 1930 & $\mathbf{F}$ & $\begin{array}{l}\text { Anaemia and splenomegaly in } \\
\text { infancy. Multiple fractures }\end{array}$ & & Osteopetrosis (AR) \\
\hline 4 & 1935 & 1929 & $\mathbf{F}$ & $\begin{array}{l}\text { Septic arthritis of left hip with } \\
\text { osteomyelitis }\end{array}$ & Affected mother & Osteopetrosis (AD) \\
\hline 5 & 1936 & 1863 & $\mathbf{F}$ & $\begin{array}{l}\text { Asymptomatic. Chance } \\
\text { diagnosis at age of } 70\end{array}$ & & Osteopetrosis (AD) \\
\hline 6 & 1936 & 1913 & $\mathbf{M}$ & $\begin{array}{l}\text { Asymptomatic. Single } \\
\text { fracture at age of } 23\end{array}$ & & Osteopetrosis (AD) \\
\hline 7 & 1945 & 1940 & $\mathbf{M}$ & $\begin{array}{l}\text { Bone pain. Fractures during } \\
\text { childhood. Coxa vara }\end{array}$ & & Osteopetrosis (AD) \\
\hline 8 & 1945 & 1933 & $\mathbf{M}$ & $\begin{array}{l}\text { Digital dislocation and deformity. } \\
\text { Patchy bony sclerosis }\end{array}$ & & Undiagnosable \\
\hline 9 & 1945 & 1910 & $\mathbf{F}$ & Fractures during second decade & Mother of Patient 19 & Osteopetrosis (AD) \\
\hline 10 & 1946 & 1942 & $\mathbf{M}$ & Coxa vara & & Osteopetrosis (AD) \\
\hline 11 & \multicolumn{6}{|c|}{ Notes missing from the collection } \\
\hline 12 & 1947 & 1939 & $\mathbf{F}$ & Coxa vara. Hip pain at age of 7 & & Osteopetrosis (AD) \\
\hline 13 & 1948 & 1924 & $\mathbf{M}$ & $\begin{array}{l}\text { Multiple fractures. Renal lesion. } \\
\text { Deaf }\end{array}$ & & Undiagnosable \\
\hline 14 & 1948 & 1946 & $\mathbf{M}$ & $\begin{array}{l}\text { Anaemia, hepatosplenomegaly } \\
\text { and optic atrophy }\end{array}$ & & Osteopetrosis (AR) \\
\hline 15 & 1949 & 1924 & $\mathbf{F}$ & $\begin{array}{l}\text { Symptom-free except for arm } \\
\text { and neck pain }\end{array}$ & & $\begin{array}{l}\text { Atypical craniodiaphyseal } \\
\text { dysplasia }\end{array}$ \\
\hline 16 & 1950 & 1945 & $\mathbf{M}$ & $\begin{array}{l}\text { Hepatosplenomegaly, lymph- } \\
\text { adenopathy and anaemia }\end{array}$ & & Osteopetrosis (AR) \\
\hline 17 & 1948 & 1947 & $\mathbf{F}$ & $\begin{array}{l}\text { Asymptomatic. Prominent } \\
\text { mandible }\end{array}$ & $\begin{array}{l}\text { Father and grand- } \\
\text { father affected }\end{array}$ & Craniometaphyseal dysplasia \\
\hline 18 & 1952 & 1913 & $\mathbf{F}$ & $\begin{array}{l}\text { Asymptomatic. Patches of osteo- } \\
\text { sclerosis noted at age of } 9\end{array}$ & & Luetic bone disease \\
\hline 19 & 1945 & 1942 & $\mathbf{M}$ & Asymptomatic & Son of Patient 9 & Osteopetrosis (AD) \\
\hline 20 & 1954 & 1924 & $\mathbf{F}$ & $\begin{array}{l}\text { Asymptomatic. Chance } \\
\text { diagnosis at age of } 30\end{array}$ & $\begin{array}{l}\text { Affected twin sister } \\
\text { and grandmother }\end{array}$ & $\begin{array}{l}\text { Osteopathia striata with } \\
\text { cranial sclerosis }\end{array}$ \\
\hline 21 & 1955 & 1920 & $\mathbf{M}$ & $\begin{array}{l}\text { Fractures. Short distal } \\
\text { phalanges. Patent cranial sutures }\end{array}$ & & Pyknodysostosis \\
\hline 22 & 1955 & 1954 & $\mathbf{F}$ & $\begin{array}{l}\text { Facial palsy in early infancy. } \\
\text { Progressive deafness in child- } \\
\text { hood. Overgrowth of mandible }\end{array}$ & $\begin{array}{l}\text { Mother similarly } \\
\text { affected }\end{array}$ & Craniometaphyseal dysplasia \\
\hline
\end{tabular}

$A D=$ Autosomal dominant $\quad A R=$ Autosomal recessive

Radiographs reveal a widespread increase in bone density, which may be patchy. The skull is usually affected, with density of the calvaria and marked basal sclerosis. The vertebrae often show generalised density of the bodies. End-plate thickening and sclerosis can produce the appearance described as "sandwich vertebrae" or the "rugger-jersey spine". Transverse striations and central sclerotic foci, termed "endobones", may be present in early childhood but they are not seen after the second decade. 
There is considerable phenotypic variation and it is likely that the condition is heterogeneous. For instance, at operation, orthopaedic surgeons have reported consistency of bone varying from "chalky" to "like marble".

The stigmata of the autosomal recessive, malignant or congenita form are apparent at birth or in early infancy. Marrow dysfunction results in anaemia, hepatosplenomegaly, abnormal bleeding and failure to thrive. Death usually occurs in infancy from haemorrhage or infection and survival beyond the first decade is rare. Fractures are common. Radiographic examination reveals generalised bony sclerosis. The skull shows progressive thickening, which is most marked at the base. Transverse striations are present in the metaphyses of the long bones and endobones may develop. Undermodelling produces a flask-shaped configuration of the bone ends. The "rugger-jersey spine" is seen.

Pyknodysostosis. Patients with this condition are of short stature. The calvaria is large with frontal and occipital bulging. Closure of the cranial sutures and anterior fontanelle may not occur or may be delayed. The facial bones are underdeveloped and the mandibular angle is obtuse. Fractures often occur (Roth 1976). Dental caries may lead to osteomyelitis of the jaw. Radiographs show generalised bone sclerosis without significant interference in modelling of the long bones. The terminal phalanges are very short. Genetic transmission is autosomal recessive.

Craniometaphyseal dysplasia. The autosomal dominant form of this condition is relatively common in comparison to other disorders in the "osteopetrosis" category. Paranasal bossing may be seen in infancy and progressive expansion and thickening of the skull and mandible may cause distortion of the facies. Some degree of facial palsy or deafness is usually present due to cranial compression. The bones are not fragile and life expectancy is normal. The radiographic changes are age-related and evident by the age of five. The base of the skull shows marked sclerosis, with lesser involvement of the calvaria. The long bones have metaphyseal widening and normal diaphyses (Spiro, Hamersma and Beighton 1975).

Craniodiaphyseal dysplasia. Several reports in the early literature have referred to this extremely rare disorder as "leontiasis ossea". Overgrowth of the skull and facial bones produces a grotesque facies and cranial nerve entrapment. Radiographs show massive hyperostosis of the skull and mandible. The ribs and clavicles are widened and the diaphyses of tubular bones are undermodelled. Atypical forms exist, and delineation is incomplete (Macpherson 1974). Inheritance is probably autosomal recessive.

Osteopathia striata with cranial sclerosis. Linear striations in the long bones and ilia, which Sir Thomas termed "osteopathia striata", may be encountered by chance during radiographic examination for some unrelated purpose (Fairbank 1935). Similar bony striae may be present as a minor feature of other osteopetroses. A distinct syndrome has been described in which osteopathia striata is associated with basal sclerosis of the skull and a variable degree of calvarial thickening (Jones and Mulcahy 1968). Mild macrocephaly and deafness may occur. This particular condition, which was represented in the Collection, is apparently inherited as an autosomal dominant, with variable phenotypic expression.

\section{COMMENT}

The general category "osteopetrosis" in the Fairbank Collection encompassed a number of distinct entities. It is clear from Sir Thomas's notes that he was fully aware of this heterogeneity and that his meticulous collection of material over many years was designed to facilitate their eventual recognition and delineation.

We are grateful to the Medical Staff Committee and the Board of Governors of the Royal National Orthopaedic Hospital, for their permission for this project to be undertaken, and to Dr R. O. Murray for the provision of facilities in his department. Mr T. J. Fairbank, Orthopaedic Surgeon, Cambridge, kindly gave his approval for our work on his father's Collection.

The investigation was supported by grants from the South African Medical Research Council and the University of Cape Town Staff Research Fund.

\section{REFERENCES}

Albers-Schönberg, H. (1904) Röntgenbilder einer seltenen knochenerkrankung. Münchener Medizinische Wochenschrift, 51, 365.

Fairbank, H. A. T. (1935) Generalized diseases of the skeleton. Proceedings of the Royal Society of Medicine, 28, $1611-1619$.

Johnston, C. C., Jun., Lavy, N., Lord, T., Vellios, F., Merritt, A. D., and Deiss, W. P., Jun. (1968) Osteopetrosis. A clinical, genetic, metabolic, and morphological study of the dominantly inherited, benign form. Medicine, 47, 149-167.

Jones, M. D., and Mulcahy, N. D. (1968) Osteopathia striata, osteopetrosis, and impaired hearing. Archives of Otolaryngology, 87, $116-118$.

Macpherson, R. I. (1974) Craniodiaphyseal dysplasia, a disease or group of diseases? Journal of the Canadian Association of Radiologists, $25,22-33$.

Roth, V. G. (1976) Pyknodysostosis presenting with bilateral subtrochanteric fractures: case report. Clinical Orthopaedics and Related Research. 117, 247-253.

Spiro, P. C., Hamersma, H., and Beighton, P. (1975) Radiology of the autosomal dominant form of craniometaphyseal dysplasia. South African Medical Journal, 49, 839-842.

VOL. 60-B, No. 1, FEBRUARY 1978 